\title{
STUDI ANALISIS FAKTOR PENYEBAB DISFUNGSIONAL AUDITOR DAN UPAYA PENANGGULANGAN DISFUNSIONAL AUDITOR TERHADAP KUALITAS AUDIT PADA KANTOR AKUNTAN PUBLIK DI PROVINSI BALI \\ (Studi Kasus pada Kantor Akuntan Publik "X” di Wilayah Denpasar, Bali)
}

\author{
Nyoman Ari Surya Dharmawan
}

Jurusan S1 Akuntansi, Fakultas Ekonomi dan Bisnis, Universitas Pendidikan Ganesha, Singaraja, Indonesia

Email: arisuryadharmawan@yahoo.com

\begin{abstract}
Abstrak
Penelian ini bertujuan untuk mengetahui faktor yang mempengaruhi disfungsional auditor dan bagaimana cara penanggulangannya. Perilaku audit disfungsional merupakan tindakan auditor dalam pelaksanaan program audit yang dapat mereduksi kualitas audit secara langsung maupun tidak langsung. Penelitian ini menggunakan pendekatan kualitatif, penelitian kualitatif adalah penelitian yang menggunakan pendekatan naturalistik untuk mencari dan menemukan pengertian atau pemahaman tren tentang fenomena dalam suatu latar yang berkonteks khusus. Dalam rangka menemukan pemahaman mengenai fenomena dalam penelitian ini digunakan paradigma interpretif dengan berusaha untuk menggali dunia apa adanya, dengan pendekatanpengalaman subyektif sendiri. Paradigma ini memasukkan pemikiran filosofis dan sosiologis yang berusaha memahami dan menjelaskan dunia sosial dari titikpandang para aktor yang secara langsung terlibat di dalam proses sosial, sehingga hubungan antara peneliti dengan yang diteliti aktif bersama tidak dapat dipisahkan, bersifat ideografik dan terikat dengan nilai-nilai. Hasil penelitian ini menjelaskan bahwa perilaku disfungsional auditor (1) disebabkan karena adanya konflik kepentingan antar pihak yang terkait dalam penugasan audit. (2) tekanan anggaran waktu dalam penyelesaian laporan keuangan,kopensasi finansial yang diberikan kepada auditor dan (3) keinginan perpindahan auditor sangat mempengaruhi prilaku disfungsional auditor. Utuk bentuk penanggulangannya sangat diperlukan peranan pemerintah dalam hal ini IAI yang menentukan regulasi dan sangat ampuh dalam menekan prilaku disfungsional auditor.
\end{abstract}

Kata kunci : prilaku, disfungsional auditor, dan bentuk penanggulangan

\begin{abstract}
Study presented here aims to determine the factors that influence the auditor dysfunctional and how to overcome them. Dysfunctional audit behavior is any act of auditors in the implementation of the audit program which can reduce the quality
\end{abstract}


of audits, directly or indirectly. This study used a qualitative approach, qualitative research is a study using a naturalistic approach to search and find the meaning or understanding of the phenomenon of trends in a specific contextual background. In order to find an understanding of the phenomenon in this study used the interpretive paradigm seeks to explore the world as it is, with its own subjective approach experience. This paradigm incorporate philosophical and sociological thought which seeks to understand and explain the social world of point of view the actors who are directly involved in the social process, so that the relationship between the researcher and the researched active joint can not be separated, are ideographic and tied with values. The results of this study that dysfunctional behavior auditors promoted due to a conflict of interest between the parties related to the audit assignment, in this case the accounting firm, the client and the auditor. Time budget pressure in the completion of the financial statements, financial compensation given to the auditor, the auditor displacement and desire greatly affect the auditor dysfunctional behavior. The role of the government in this case IAI, highly potent in suppressing the dysfunctional behavior of auditors.

Keywords: dysfunctional, behavior auditor, and response form

\section{PENDAHULUAN}

Pertumbuhan dunia usaha di Bali sangatlah pesat, ini ditunjang dari tingkat pertumbuhan pariwisata yang terus-menerus meningkat secara signifikan. Seiring dengan pesatnya pertumbuhan dunia usaha di Bali maka secara tidak langsung akan memicu banyaknya investor asing maupun investor dalam negeri yang ingin menanamkan modalnya di Bali. Sebelum menanamkan modalnya, para investor mencari informasi-informasi yang dapat dipercaya kebenarannya. Salah satu informasi yang dibutuhkan adalah informasi keuangan. Informasi keuangan merupakan salah satu indikator, dimana dapat dikatakan suatu perusahaan berjalan secara baik atau optimal. Untuk mengetahui informasi tersebut dapat dikatan berkualitas, maka diperlukannya audit.

Audit sering dipandang sebagai assurance service yaitu jasa profesional independen yang dapat meningkatkan kualitas informasi bagi pengambil keputusan. Peningkatan kualitas informasi akan meningkatkan kepercayaan pengguna informasi terhadap informasi yang disajikan. Karena fungsi audit sebagai jasa penjamin bahwa suatu informasi yang disajikan adalah informasi yang kredibel maka kompetensi, kemampuan dan independensi pihak yang melakukan audit (auditor) menjadi hal penting yang harus diperhatikan dan dipertahankan dalam proses pengauditan. Untuk menjaga dan memberikan jaminan kepada pemakai jasa auditor tentang independensi dan profesionalitas auditor, profesi telah menetapkan kode etik akuntan publik dan kontrol kualitas. Kode etik akuntan mengatur apa yang boleh dan apa yang tidak boleh dilakukan oleh seorang akuntan dan bagaimana akuntan harus bertindak agar tidak merugikan salah satu pihak dan menguntungkan pihak yang lain. Kode etik juga mengatur hubungan dan bagaimana komunikasi akuntan dengan akuntan lain harus dilakukan sehingga pemberian jasa tetap profesional. Selain kode etik akuntan, profesi juga 
menetapkan kontrol kualitas terhadap profesi akuntan dengan cara melakukan review atau pemeriksaan secara berkala baik yang dilakukan oleh profesi maupun yang dilakukan atar akuntan publik (peer review) dibawah pengawasan asosiasi profesi dan departemen keuangan. Review dilakukan untuk menghidari kesalahan dan ketidaktaatan terhadap prosedur dan program audit yang telah ditetapkan berdasarkan standar audit dan standar profesi.

Perilaku disfungsional auditor disebabkan karena adanya konflik kepentingan antar pihak yang terkait dalam penugasan audit, dalam hal ini adalah kantor akuntan, klien dan auditor (Sujana, 2010). Konflik yang paling sering terjadi adalah antara klien dan auditor. Klien adalah perusahaan yang memberikan tugas dan membayar auditor untuk melakukan audit dan klien memiliki kepentingan agar laporan keuangan perusahaanya dapat diberikan opini terbaik. Disisi lain, auditor adalah orang yang harus independen sesuai dengan amanat Standar Audit dan Kode Etik Akuntan, dan harus memberikan opini terhadap laporan keuangan apa adanya. Konflik kepentingan seperti ini seringkali menjerumuskan auditor untuk berperilaku disfungsional. Fenomena perilaku penyimpangan (perilaku disfungsional) yang dilakukan akuntan publik di Indonesia cukup mengkhawatirkan. Departemen Keuangan sebagai pengawas Akuntan Publik dan Kantor Akuntan Publik hampir setiap tahun mengeluarkan Surat Keputusan Pembekuan Ijin Akuntan Publik. Sejak Departemen Keuangan

mengintensifkan pengawasannya pada tahun 2002, tercatat ada 10 Kantor Akuntan dibekukan ijin operasinya. Selanjutnya pada tahun 2003 tercatat 5 Akuntan Publik dibekukan ijin operasinya karena melakukan pelanggaran terhadap Standar Profesional Akuntan Publik (Mayangsari, 2003). Sedangkan pada tahun 2005, 2006 2008, dan 2009 Departemen Keuangan kembali mengumumkan pembekuan 5 ijin Akuntan Publik.

Pembekuan Kantor Akuntan Publik oleh Departemen Keuangan dilakukan tanggal 11 Juni 2008 lalu terhadap KAP Drs Tahir Hidayat dan Dody Hapsoro dengan Keputusan Menteri Keuangan Nomor 397/KM.1/2008. Pembekuan dilakukan karena yang bersangkutan telah melakukan pelanggaran terhadap Standar Auditing (SA) - Standar Profesional Akuntan Publik (SPAP) dalam pelaksanaan audit atas laporan keuangan konsolidasi PT Pupuk Sriwidjaya (Pesero) dan anak perusahaannya. (Bali Post, Juni 2008).

Fonemena ini juga terjadi pada Kantor Akuntan Publik (KAP) diwilayah provensi Bali. Di provinsi bali tercatat ada 8 (delapan) KAP, diantaranya 2 KAP pernah dibekukan ijinnya oleh Kementrian Keuangan selama 6 (enam) bulan. Salah satu Kantor Akuntan Publik yang pernah dibekukan ijinnya adalah KAP Gunarsa. Pembekuan dilakukan karena yang bersangkutan telah melakukan pelanggaran terhadap Standar Auditing (SA) - Standar Profesional Akuntan Publik (SPAP) dalam pelaksanaan audit atas laporan keuangan dana pensiun pada PT. Bank Dagang Bali pada tahun 2009. 
Penelitian (Hwang dan Chang, 2010) menemukan bahwa lingkungan audit dan tekanan klien cenderung akan mempengaruhi keputusan auditor dalam menerima pelaporan keuangan yang agresif (manipulatif). Hal ini menunjukkan bahwa tekanan oleh klien telah menyebabkan auditor melakukan penyimpangan terhadap prosedur audit. Tekanan dari klien memang akan selalu terjadi karena auditor dibayar oleh klien, tetapi disisi lain auditor dibatasi oleh kode etik dan standar auditing, yang mengharuskan auditor tetap independen dalam segala situasi.

Berdasarkan latar belakang diatas, penelitian ini akan mencoba untuk mengidentifikasi, menganalisis penyebab perilaku disfungsional auditor dan upaya penanggulangan disfungsional auditor agar lebih menjamin kualitas audit yang dilakukan oleh auditor eksternal pada kantor KAP provensi Bali.

Audit memberikan nilai tambah pada laporan keuangan perusahaan, karena akuntan publik sebagai pihak yang ahli dan independen pada akhir pemeriksaannya akan memberikan pendapat mengenai kewajaran posisi keuangan, hasil usaha, perubahan ekuitas dan laporan arus kas.

Sebagai seorang yang profesional akuntan harus selalu menjaga sikap mental independen. Sekalipun akuntan adalah ahli, apabila tidak memiliki sikap independen dalam mengumpulkan informasi akan tidak berguna, sebab informasi yang digunakan untuk mengambil keputusan haruslah tidak bias. Independensi merupakan suatu yang harus selalu diupayakan, karena dengan independensi kepercayaan pemakai laporan auditor akan bisa dicapai. Kepercayaan pemakai laporan auditor sangat menentukan masa depan profesi.

Oleh karena akuntan publik memainkan peran sosial yang penting, Akunntan Publik dan staff dituntut untuk berperilaku yang pantas dalam melakukan audit dan jasa akutan lainnya dengan kualitas yang tinggi. Untuk itu asosiasi profesi akuntan, menyusun Standar Auditing. Standar auditing ini merupakan pedoman bagi auditir dalam menjalankan tanggung jawab profesionalnya. Standar-standar ini meliputi pertimbangan mengenai kualitas profesional seperti keahlian dan independensi, persyaratan pelaporan dan bahan bukti.

Di Indonesia, Standar auditing disusun oleh Ikatan Akuntan Indonesia (IAI), yang mana Standar Auditing tersebut merupakan hasil adopsi dari Standar Auditing di Amerika yang disusun oleh AICPA. Standar Auditing terdiri dari sepuluh standar yang merupakan pedoman bagi auditor dalam melakukan pekerjaannya. Kesepuluh Standar Auditing tersebut yaitu :

1. Audit harus dilaksanakan oleh seseorang atau lebih yang memiliki keahlian dan pelatihan teknis cukup sebagai auditor.

2. Dalam semua hal yang berhubungan dengan penugasan, independensi dan sikap mental harus dipertahankan oleh auditor.

3. Dalam melaksanakan audit dan penyusunan laporannya, auditor wajib menggunakan kemahiran profesionalnya dengan cermat dan seksama.

4. Pekerjaan harus direncanakan sebaik-baiknya dan jika digunakan 
asisten harus disupervisi dengan semestinya.

5. Pemahaman yang memadai atas struktur pengendalian intern harus diperoleh untuk merencanakan audit dan menentukan sifat, saat dan lingkup pengujian yang harus dilakukan.

6. Bukti audit kompeten yang cukup harus diperoleh melalui inspeksi, pengamatan, pengajuan pertanyaan dan konfirmasi sebagai dasar yang memadai untuk menyatakan pendapat atas laporan kauangan yang diaudit.

7. Laporan audit harus menyatakan apakah laporan keuangan telah disusun sesuai dengan prinsip akuntans yang berlaku umum.

8. Laporan audit harus menunjukkan keadaan yang didalamnya prinsip akuntansi tidak secara konsisten diterapkan dalam penyusunan laporan keuangan periode berjalan dalam hubungannya dengan prinsip akuntansi yang diterapkan dalam periode sebelumnya.

9. Pengungkapan informatif dalam laporan keuangan harus dipandang memadai, kecuali dinyatakan lain dalam laporan audit.

10. Laporan audit harus memuat suatu pernyataan pendapat mengenai laporan keuangan secara keseluruhan atau suatu asersi bahwa pernyataan demikian tidak dapat diberikan. Jika pendapat secara keseluruhan tidak dapat diberikan, maka alasannya harus dinyatakan. Dalam semua hal yang mana auditor dihubungkan dengan laporan keuangan, laporan auditor harus memuat petunjuk yang jelas mengenai sifat pekerjaan auditor, jika ada, dan tingkat tanggung jawab yang dipikulnya.

Standar Auditing ini dijabarkan lagi kedalam Pernyataan Standar Auditing (PSA) yang merupakan pedoman kerja yang paling utama bagi para auditor. Pernyataan Standar Auditing dianggap sebagai ketentuan yang memiliki nilai hukum karena setiap orang dalam profesi ini wajib mematuhi sesuai aplikasinya.

Kajian pustaka mengenai perilaku disfungsional auditor telah dilakukan oleh berbagai ahli. Perilaku disfungsional auditor merupakan perilaku menyimpang yang dilakukan auditor dalam melaksanakan audit yang dapat secara langsung ataupun tidak langsung mengurangi kualitas audit (Kelley and Margheim, 1990; Otley and Pierce, 1996). Perilaku disfungsional auditor dibedakan sebagai berikut :

\section{Tindakan yang tidak secara langsung mempengaruhi kualitas audit.}

Underreporting of time yaitu mencerminkan suatu keadaan yang menunjukkan auditor menyelesaikan pekerjaan atau tugas yang dibebankan dengan waktu pribadi dan dimotivasi oleh keinginan untuk menghindari atau meminimumkan anggaran yang berlebih. (Commission on Auditor's Responsibilities Report, 1978 dalam Otley and Pierce, 1996b)

\section{Tindakan yang mengurangi kualitas audit.}

1. Penghentian premature terhadap langkah audit dalam program audit (premature sign-off). 
2. Mengurangi jumlah pekerjaan yang dikerjakan dalam langkah audit yang dianggap beralasan oleh auditor.

3. Tidak melakukan penelitian terhadap prinsip akuntansi.

4. Tidak melakukan review dengan sungguh-sungguh terhadap dokumen klien.

5. Menerima penjelasan klien yang lemah.

Teori konflik Collins bertolak dari beberapa asumsi: (1) orang dipandang mempunyai sifat sosial (sociable), tetapi juga terutama mudah berkonflik dalam hubungan sosial mereka; (2) orang berupaya untuk memaksimalkan "status subjektif" mereka dan kemampuan untuk berbuat demikian tergantung pada sumber daya mereka maupun sumber daya orang lain dengan siapa mereka berurusan; (3) orang mempunyai kepentingan sendiri-sendiri, jadi benturan mungkin terjadi karena kepentingan-kepentingan ini pada dasarnya saling bertentangan. (Ritzer and Goodman, 2004: 160)

Kepercayaan auditor bahwa mematuhi anggaran waktu berhubungan dengan penilaian kinerja, akan memaksa auditor untuk memaksakan diri memenuhi anggaran waktu walaupun harus melakukan perilaku disfungsional seperti menggunakan waktu pribadi untuk melakukan pekerjaan (underreporting of time) dan melakukan tindakan yang dapat mengurangi kualitas audit misalnya penghentian prematur terhadap prosedur audit.

Penelitian pengaruh kesesuaian kompensasi manajemen perusahaan terhadap perilaku tidak etis dan kecenderungan dilakukannya kecurangan akuntansi oleh manajemen perusahaan telah diteliti oleh Wilopo, 2006. Penelitian tersebut menyatakan bahwa kesesuaian kompensasi menyebabkan perilaku tidak etis manajemen perusahaan yang menimbulkan kecenderungan melakukan kecurangan akuntansi. Auditor yang tidak memperoleh kompensasi yang memuaskan dari kantor akuntan cenderung akan tidak memiliki komitmen tinggi terhadap pekerjaan, dan cenderung akan mencari tempat kerja yang lebih baik sehingga keinginan untuk bertahan di kantar akuntan tersebut akan rendah. Keinginan bertahan yang rendah berpotensi menimbulkan perilaku disfungsional auditor (Malone and Robert, 1996; Donnelly et al., 2003).

Tekanan anggaran waktu yang dialami auditor dapat menimbulkan stress, dan stress akan menimbulkan keinginan auditor untuk berpindah kantor (Kelley and Seiler, 1982; Cook and Kelley, 1988). Kelley and Seiler, 1982 menyatakan bahwa tekanan anggaran waktu merupakan masalah besar bagi auditor, dan hasil surveynya menunjukkan bahwa 8\% auditor percaya bahwa tekanan anggaran waktu akan meningkatkan keinginan berpindah dari auditor. Sedangkan Cook and Kelley, 1988 menemukan 6\% auditor percaya bahwa tekanan anggaran waktu akan meningkatkan keinginan berpindah auditor.

Kompensasi berupa uang sudah sejak lama diketahui sebagai faktor yang menentukan dalam memilih pekerjaan dan merupakan alasan untuk berpindah pekerjaan. Seperti pada penelitian (Koh and Goh, 1995) menemukan bahwa financial reward 
berpengaruh pada keinginan berpindah pada klerikal staff di Singapura. Demikian juga penelitian (Tekleab et al., 2005) menemukan bahwa peningkatan gaji secara signifikan menyebabkan rendahnya keinginan berpindah auditor.

Keinginan berpindah auditor adalah merupakan konsekuensi dari ketidakpuasan auditor terhadap pekerjaan yang dilakukannya saat ini. Ketidak puasan kerja dapat disebabkan oleh berbagai faktor seperti lingkungan kerja, gaji, kepemimpinan dan lain sebagainya. Ketidakpuasan auditor terhadap pekerjaan akan menimbulkan perasaan tidak suka, kesal bahkan benci terhadap kantor akuntan tempatnya bekerja. Perasaan ini akan memicu keinginan berpindah dari auditor.

Pemikiran Collins tentang konflik kepentingan dalam persepektif mikro merupakan alat analisis yang cukup tepat untuk menganalisa perilaku disfungsional auditor. Collins menyatakan "organisasi formal sebagai jaringan pengaruh interpersonal dan sebagai arena di mana kepentingan yang bertentangan dimainkan." Kantor Akuntan Publik (KAP) merupakan arena sosial yang didalamnya pastilah terjadi interaksi yang kompleks, baik itu interaksi yang antar individu maupun interaksi institutif.

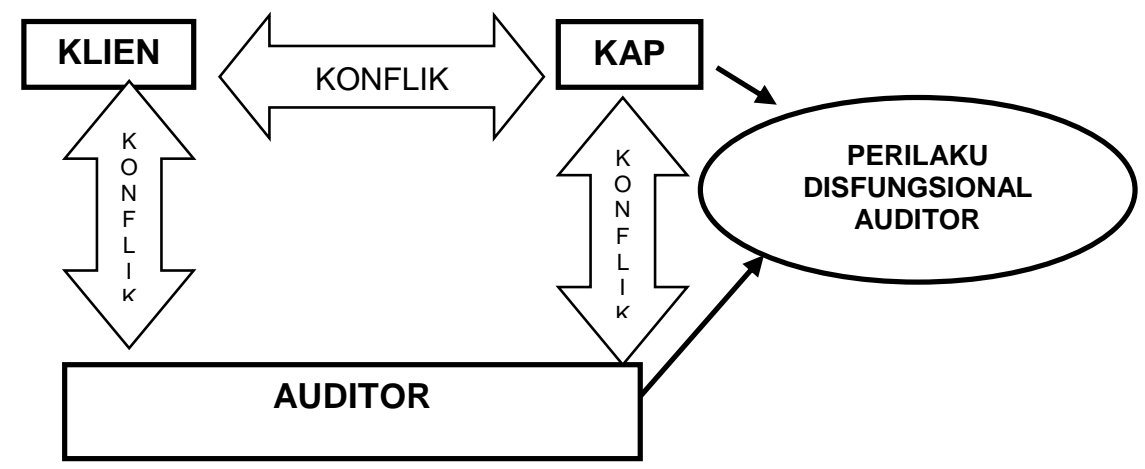

Gambar. 1 Skema Konflik Kepentingan KAP, Auditor dan Klien

\section{METODE}

Penelitian ini menggunakan pendekatan kualitatif. Penelitian kualitatif adalah penelitian yang menggunakan pendekatan naturalistik untuk mencari dan menemukan pengertian atau pemahaman tentang fenomena dalam suatu latar yang berkonteks khusus.

Penelitian ini dilakukan dalam di Kantor Akuntan Publik. Penelitian difokuskan pada auditor yang bekerja pada sebuah Kantor Akuntan Publik (KAP) di Kota Denpasar-Bali. Kantor Akuntan yang dipilih adalah Kantor Akuntan Publik "X" yang berlokasi Denpasar. Alasan merahasikan nama kantor akuntan ini adalah mejaga kredibilitas dan nama baik dari kantor akuntan itu dan juga karena ada teman peneliti yang menjadi manajer pada KAP tersebut sehingga memudahkan peneliti untuk diterima 
bekerja menjadi auditor part-time pada KAP tersebut.

Data dan informasi yang dibutuhkan untuk menjawab masalah penelitian dikumpulkan melalui beberapa teknik pengumpulan data sebagai berikut: Observasi dilakukan dengan menerapkan observasi partisipasi (participant observation) yaitu peneliti berusaha terlibat di dalam suatu proses kehidupan sosial sehari-hari di mana interaksi sosial berlangsung.

Dengan peneliti "menjadi bagian" dari KAP dan terlibat dalam kegiatan sehari-hari, maka otomatis akan terlibat dalam dialog-dialog interaktif dengan para staff profesional (auditor) pada KAP tersebut. Dialog ini merupakan wawancara yang berlangsung secara alamiah, mendalam, bersifat informal dan tidak tersetruktur. Wawancara ini dilakukan peneliti terhadap klien, auditor maupun pimpinan KAP.

Teknik pengumpulan data lainnya adalah studi dokumen. Dokumen yang dikaji antara lain dokumen hasil pemeriksaan auditor pada Kantor Akuntan Publik (KAP), dokumen tersebut meliputi, kertas kerja pemeriksaan, hasil perhitungan fisik, hasil konfirmasi, program audit, audit prosedur maupun buku-buku atau dokumen lain terkait dengan penelitian.

Dalam rangka lebih memudahkan pemahaman terhadap keterkaitan antara masalah penelitian, tehnik pengumpulan data dan sumbernya dapat disajikan pada tabel berikut:

Tabel. 1 Keterkaitan Masalah dengan Teknik Pengumpulan Data dan Sumber Data

\begin{tabular}{|c|c|c|c|}
\hline No. & Masalah Penelitian & Sumber Data & $\begin{array}{l}\text { Metode/Teknik } \\
\text { Pengumpulan } \\
\text { Data }\end{array}$ \\
\hline 1. & $\begin{array}{l}\text { Faktor-faktor apa yang } \\
\text { mendorong auditor } \\
\text { pada Kantor Akuntan } \\
\text { Publik melakukan } \\
\text { perilaku disfungsional } \\
\text { ketika melaksanakan } \\
\text { tugas pengauditan }\end{array}$ & $\begin{array}{l}\text { Pengamatan terhadap hubungan Auditor- } \\
\text { Klien, KAP-Klien dan Auditor-KAP } \\
\text { Nara sumber wawancara adalah auditor, } \\
\text { klien, manajer dan partner } \\
\text { Dokumentasi yang ditelaah adalah } \\
\text { dokumen hasil pemeriksaan, prosedur } \\
\text { audit yang dilakukan, bukti-bukti } \\
\text { pemeriksaan dll. }\end{array}$ & $\begin{array}{l}\text { Pengamatan } \\
\text { partisipasi, } \\
\text { wawancara } \\
\text { mendalam dan } \\
\text { studi } \\
\text { dokumentasi }\end{array}$ \\
\hline 2. & $\begin{array}{lr}\text { Bagaimana } & \text { bentuk- } \\
\text { bentuk } & \text { perilaku } \\
\text { disfungsional } & \text { yang } \\
\text { dilakukan oleh auditor } \\
\text { pada Kantor } & \text { Akuntan } \\
\text { Publik } & \text { ketika } \\
\text { melakukan } & \\
\text { pengauditan } & \end{array}$ & $\begin{array}{l}\text { Pengamatan terhadap hubungan Auditor- } \\
\text { Klien, KAP-Klien dan Auditor-KAP } \\
\text { Nara sumber wawancara adalah auditor, } \\
\text { klien, manajer dan partner } \\
\text { Dokumentasi yang ditelaah adalah } \\
\text { dokumen hasil pemeriksaan, prosedur } \\
\text { audit yang dilakukan, bukti-bukti } \\
\text { pemeriksaan dll. }\end{array}$ & $\begin{array}{l}\text { Pengamatan } \\
\text { partisipasi, } \\
\text { wawancara } \\
\text { mendalam dan } \\
\text { studi } \\
\text { dokumentasi }\end{array}$ \\
\hline 3. & $\begin{array}{l}\text { Bagaimana upaya } \\
\text { yang dapat dilakukan } \\
\text { Oleh Kantor Akuntan } \\
\text { Publik dan asosiasi } \\
\text { profesi untuk dapat }\end{array}$ & $\begin{array}{l}\text { Nara sumber wawancara adalah Auditor, } \\
\text { Manajer dan Partner } \\
\text { Dokumentasi yang ditelaah adalah } \\
\text { dokumen hasil pemeriksaan, prosedur } \\
\text { audit yang dilakukan, bukti-bukti }\end{array}$ & $\begin{array}{l}\text { Wawancara } \\
\text { mendalam dan } \\
\text { studi } \\
\text { dokumentasi }\end{array}$ \\
\hline
\end{tabular}




\begin{tabular}{|l|l|l|l|}
\hline $\begin{array}{l}\text { menghindarkan auditor } \\
\text { beperilaku } \\
\text { disfungsional }\end{array}$ & pemeriksaan dll. & \\
\hline
\end{tabular}

\section{HASIL DAN PEMBAHASAN}

Faktor-faktor yang mendorong auditor pada Kantor Akuntan Publik melakukan perilaku disfungsional ketika melaksanakan tugas pengauditan.

Prilaku yang medorong auditor dalam melakukan disfungsional auditor adalah

A. Tindakan yang tidak secara langsung mempengaruhi kualitas audit.

1. Underreporting of time yaitu mencerminkan suatu keadaan yang menunjukkan auditor menyelesaikan pekerjaan atau tugas yang dibebankan dengan waktu pribadi dan dimotivasi oleh keinginan untuk menghindari atau meminimumkan anggaran yang berlebih. (Commission on Auditor's Responsibilities Report, 1978 dalam Otley and Pierce, 1996b)

B. Tindakan yang mengurangi kualitas audit.

1. Penghentian premature terhadap langkah audit dalam program audit (premature sign-off).

2. Mengurangi jumlah pekerjaan yang dikerjakan dalam langkah audit yang dianggap beralasan oleh auditor.

3. Tidak melakukan penelitian terhadap prinsip akuntansi.

4. Tidak melakukan review dengan sungguh-sungguh terhadap dokumen klien.

5. Menerima penjelasan klien yang lemah.

Berdasarkan hasil pengamatan yang dilakukan melalui proses observasi, wawancara dan studi dokumentasi yg telah dilakukan mengindikasikan bahwa uditor KAP "GA" telah melakukan pekerjaan sesuai dengan standar profesi dan standar audit yg telah ditetapkan.

\section{Bentuk-bentuk perilaku disfungsional yang dilakukan oleh auditor pada Kantor Akuntan Publik ketika melakukan pengauditan.}

Bentuk-bentuk prilaku disfungsional yang dilakukan oleh auditor pada Kantor Akuntan Publik ketika melakukan pengauditan adalah :

1. Tekanan anggaran waktu yang diberikan oleh klien maupun Kantor Akuntan Publik kepada auditor

2. Kompesansi finansial yang diberikan oleh klien terhadap Kantor Akuntan Publik dan Kantor Akuntan Publik terhadap auditor

3. Keinginan untuk berpindah Auditor yang dilakukan oleh klien.

Berdasarkan hasil pengamatan yang dilakukan melalui proses observasi, wawancara dan studi dokumentasi yg telah dilakukan auditor kantor KAP "GA" tidak melakukan prilaku disfungsional audit ini dikarenakan anggaran waktu yang telah sesuai di terapkan, kompensasi finansial yang diberikan sesuai dengan pekerjaan yg dilakukan, dan kenyamanan dalam melakukan pekerjaan. 
Upaya yang dapat dilakukan oleh Kantor Akuntan Publik dan asosiasi profesi untuk dapat menghindarkan auditor beperilaku disfungsional

Berdasarkan hasil pengamatan yang dilakukan melalui proses observasi, wawancara dan studi dokumentasi yg telah dilakukan dapat disimpulkan bahwa Upaya yang dapat dilakukan oleh Kantor Akuntan Publik dan asosiasi profesi untuk dapat menghindarkan auditor beperilaku disfungsional adalah dengan mematuhi standar yang telah ditetapkan oleh IAI yaitu standar profesi dan standar audit dan juga adanya peraturan atau regulasi yang yang telah diatur dalam peraturan mentri keuangan nomor 17/PMK.01/2008.

a. Menjaga komitmen professional auditor dengan Teori konflik Collins bertolak dari beberapa asumsi: (1) orang dipandang mempunyai sifat sosial (sociable), tetapi juga terutama mudah berkonflik dalam hubungan sosial mereka; (2) orang berupaya untuk memaksimalkan "status subjektif" mereka dan kemampuan untuk berbuat demikian tergantung pada sumber daya mereka maupun sumber daya orang lain dengan siapa mereka berurusan; (3) orang mempunyai kepentingan sendiri-sendiri, jadi benturan mungkin terjadi karena kepentingan-kepentingan ini pada dasarnya saling bertentangan. (Ritzer and Goodman, 2004: 160), seperti :

\section{Tekanan Anggaran Waktu dan Perilaku Disfungsional Auditor}

Kepercayaan auditor bahwa mematuhi anggaran waktu berhubungan dengan penilaian kinerja, akan memaksa auditor untuk memaksakan diri memenuhi anggaran waktu walaupun harus melakukan perilaku disfungsional seperti menggunakan waktu pribadi untuk melakukan pekerjaan (underreporting of time) dan melakukan tindakan yang dapat mengurangi kualitas audit misalnya penghentian prematur terhadap prosedur audit.

\section{Kompensasi Finansial dan Perilaku Disfungsional Auditor \\ Penelitian pengaruh kesesuaian} kompensasi manajemen perusahaan terhadap perilaku tidak etis dan kecenderungan dilakukannya kecurangan akuntansi oleh manajemen perusahaan telah diteliti oleh Wilopo, 2006. Penelitian tersebut menyatakan bahwa kesesuaian kompensasi menyebabkan perilaku tidak etis manajemen perusahaan yang menimbulkan kecenderungan melakukan kecurangan akuntansi. Auditor yang tidak memperoleh kompensasi yang memuaskan dari kantor akuntan cenderung akan tidak memiliki komitmen tinggi terhadap pekerjaan, dan cenderung akan mencari tempat kerja yang lebih baik sehingga keinginan untuk bertahan di kantar akuntan tersebut akan rendah. Keinginan bertahan yang rendah berpotensi menimbulkan perilaku disfungsional auditor (Malone and Robert, 1996; Donnelly et al., 2003).

\section{Tekanan Anggaran Waktu dan Keinginan Berpindah Auditor \\ Tekanan anggaran waktu yang} dialami auditor dapat menimbulkan stress, dan stress akan menimbulkan 
keinginan auditor untuk berpindah kantor (Kelley and Seiler, 1982; Cook and Kelley, 1988). Kelley and Seiler, 1982 menyatakan bahwa tekanan anggaran waktu merupakan masalah besar bagi auditor, dan hasil surveynya menunjukkan bahwa 8\% auditor percaya bahwa tekanan anggaran waktu akan meningkatkan keinginan berpindah dari auditor. Sedangkan Cook and Kelley, 1988 menemukan 6\% auditor percaya bahwa tekanan anggaran waktu akan meningkatkan keinginan berpindah auditor.

\section{Kompensasi Finansial dan Keinginan Berpindah Auditor Kompensasi berupa uang sudah} sejak lama diketahui sebagai faktor yang menentukan dalam memilih pekerjaan dan merupakan alasan untuk berpindah pekerjaan. Seperti pada penelitian (Koh and Goh, 1995) menemukan bahwa financial reward berpengaruh pada keinginan berpindah pada klerikal staff di Singapura. Demikian juga penelitian (Tekleab et al., 2005) menemukan bahwa peningkatan gaji secara signifikan menyebabkan rendahnya keinginan berpindah auditor.

\section{Keinginan Berpindah Auditor dan Perilaku Disfungsional Auditor} Keinginan berpindah auditor adalah merupakan konsekuensi dari ketidakpuasan auditor terhadap pekerjaan yang dilakukannya saat ini. Ketidak puasan kerja dapat disebabkan oleh berbagai faktor seperti lingkungan kerja, gaji, kepemimpinan dan lain sebagainya. Ketidakpuasan auditor terhadap pekerjaan akan menimbulkan perasaan tidak suka, kesal bahkan benci terhadap kantor akuntan tempatnya bekerja. Perasaan ini akan memicu keinginan berpindah dari auditor.

\section{PENUTUP}

Berdasarkan hasil penelian yang telah dilaksanakan maka dapat ditarik kesimpulan bahwa auditor kantor KAP "X" dalam melakukan audit tidak melakukan disfungsional auditor karena dalam melakukan audit mengikuti standar dan peraturan yang telah ditentukan atau ditetapkan.

\section{DAFTAR PUSTAKA}

Hwang N.C.R and Chang C.J., 2010, Litigation environment and auditor's decision to accept client's aggressive reporting, Journal Account Public Policy, Vo. 29, p.281-295

Kelley, T., and Margheim, L , 1990, The Impact of Time Budget Pressure, Personality and Leadership Variable on Disfunctional Auditor Behavior, Auditing: A Journal of Practice \& Theory, 9.

Kelley T., Margheim L. and Pattison D., 1999, Survey On The Differential Effects of Time Deadline Pressure Versus Time Budget Pressure on Auditor Behaviour, The Journal of Applied Business Research, Vol. 15, No.4, pp 117-128

Kelley, T. and Margheim, L., 2002, The Relationships Between Senior Auditor Budget Participation, Job Structuring, Job Consideration And Staff Auditor Time Budget Pressure, The Journal of Applied 
Business Research, Vol. 18, No. 2.

Kelley, T. and R.E. Seiler, 1982, Auditor Stress and Time Budgets, The CPA Journal, Dec 1982, p. 2434

Kirschenbaum, A. and J. Weisberg, 2002, Journal of Organizational Behavior, Vol. 23, p.109-125

Koh, H.C and Goh, C.T., 1995, An Analysis of The Factors Affecting the Turnover Intention of non-managerial clerical staff: A Singapore Study, The International Journal of Human Resource Management, Vol. 6, p.103125

Koswara, E., 1991, Teori-teori Kepribadian, PT. Eresco, Bandung

Luthans Fred, 1998, Organizational Behaviour, Eighth Edition, McGraw Hill, USA

Malone, C. F.and R. W. Roberts, 1996, Factors Associated with the Incidence of Reduced Audit Quality Behaviors, Auditing: A Journal of Practice \& Theory, Vol. 15, No.2, p.49-64

Morris S.A and McDonald R.A, 1995, The Role of Moral Intensity in Moral Judgement: An Empirical Investigation, Journal of Business Ethics, 14, p. 715726
Muawanah, U. dan N. Indriantoro, 2001, Perilaku Auditor dalam Situasi Konflik Audit: Peran Locus of Control, Komitmen Profesi dan Kesadaran Etis, Jurnal Riset Akuntansi Indonesia, Vol. 4, No. 2, p. 133-150.

Otley,D. T. and Pierce B.J.,1996, Auditor Time Budget Pressure : Consequences and Antecedents, Accounting, Auditing and Accountability Journal, Vol. 9, No. 1, pp. 3158

Otley, D. T. and B. J. Pierce, 1996, The Operation of Control Systems in Large Audit Firms, Auditing: A Journal of Practice \& Theory, Vol. 15, No. 2, p. 65-84.

Ponemon, L.A., 1992, Auditor underreporting of time and moral reasoning: An experimental lab study, Contemporary Accounting Research, Vol. 9, no. 1, p. 171189

Ritzer G. and Goodman D., 2004, Teori Sosiologi Modern, Edisi Keenam, Prenada Media, Jakarta

Sujana E., 2010, Perilaku Disfungsional Auditor: Tinjauan terhadap konfik kepentingan, Jurnal Sosio Religia, Vol. 9 Edisi Khusus, p. 513-533. 